\title{
Genome Walking with 2- to 4-kb Steps Using Panhandle PCR
}

\author{
Douglas H. Jones and Stanley C. Winistorfer
}

Department of Pediatrics, University of Iowa College of Medicine, Iowa City, Iowa 52242-1083

\begin{abstract}
Panhandle PCR is a method that permits the rapid retrieval of DNA segments flanking a known DNA sequence. This method extends the application of PCR to the retrieval of DNA where only one end of the DNA sequence is known, so that one can use PCR to walk along an uncharacterized stretch of DNA. In this report, we demonstrate that this method can be applied to the highly specific retrieval of large pieces (2.2-4.4 kb) of human genomic DNA that flank the primer annealing sites.
\end{abstract}

$\mathbf{T}$ he PCR permits the highly specific amplification of DNA sequences, but requires knowledge of the sequences that flank both ends of the sequence of interest. $^{(1-3)}$ Several methods have been developed to permit the PCR amplification of unknown DNA that flanks one end of a known sequence. ${ }^{(4-23)}$ The number and variety of methods developed to amplify DNA flanking a known sequence attest to the scientific need for an effective method. None of the existing methods, apart from panhandle PCR, ${ }^{(23)}$ has permitted the highly specific PCR amplification of $>2 \mathrm{~kb}$ of human genomic DNA that flanks a known site. This paper introduces a protocol of panhandle PCR that permits the highly specific PCR amplification of up to $4.4 \mathrm{~kb}$ of DNA flanking a known site directly from bulk human genomic DNA. The sequences retrieved were human genomic $\beta$-globin sequence $^{(24)}$ and the genomic DNA $5^{\prime}$ to the human cystic fibrosis transmembrane conductance regulator (CFTR) cDNA. ${ }^{(25-27)}$

The panhandle PCR method is illustrated in Figure 1. The steps in Figure 1 are explained in detail in the Materials and Methods section. Human genomic DNA is digested with a restriction enzyme that leaves a $5^{\prime}$ overhang. This digested DNA is treated with calf intestinal alkaline phosphatase and the ends are ligated to a $5^{\prime}$ phosphorylated singlestranded oligonucleotide, so that the $3^{\prime}$ end of each strand of digested genomic DNA is modified. The protruding singlestranded 3' ends are complementary to a region of known DNA that is upstream to the unknown region of interest. Therefore, when this complex mixture undergoes denaturation and annealing under dilute conditions that promote in- trastrand annealing, those single strands of genomic DNA that contain the complement to the 3' ends will form a stemloop structure with a recessed $3^{\prime}$ end. Therefore, the ligated oligonucleotide can prime template-directed DNA polymerization on those strands that contain the known sequence, resulting in known DNA being attached to the uncharacterized end of the unknown DNA (Fig. 1, step 3). Because this polymerization reaction results in known DNA being positioned on both sides of the unknown flanking DNA, PCR can be used to amplify the unknown DNA.

High specificity and yield are obtained by use of a hot-start strategy prior to generation of the initial PCR template (shaped like a pan with a handle; Fig. 1, step 3), followed by a hot-start PCR amplification, and then a nested hot-start PCR amplification. The rationale for nested PCR amplification and for a hotstart strategy is detailed in two previous publications. ${ }^{(1,28)}$ A hot start was accomplished by not allowing the temperature of the fully constituted polymerase reactants to drop below $80^{\circ} \mathrm{C}$ before the annealing step for priming, this temperature being well above the $T_{\mathrm{m}}$ of any of the primers. The hot start eliminates priming at low stringency, preventing the generation of nonspecific products. The $T_{\mathrm{m}}$ of the protruding singlestranded 3 ' ends created by the ligated oligonucleotide was calculated, and the annealing temperature for forming the stem-loop structure was set at $2^{\circ} \mathrm{C}$ below this $T_{\mathrm{m}}$ value. The $T_{\mathrm{m}}$ of each PCR primer was also calculated, and the annealing temperature used in each PCR amplification was approximately $2^{\circ} \mathrm{C}$ below the mean $T_{\mathrm{m}}$ of each primer set. Two primers are used in each PCR amplifica- 


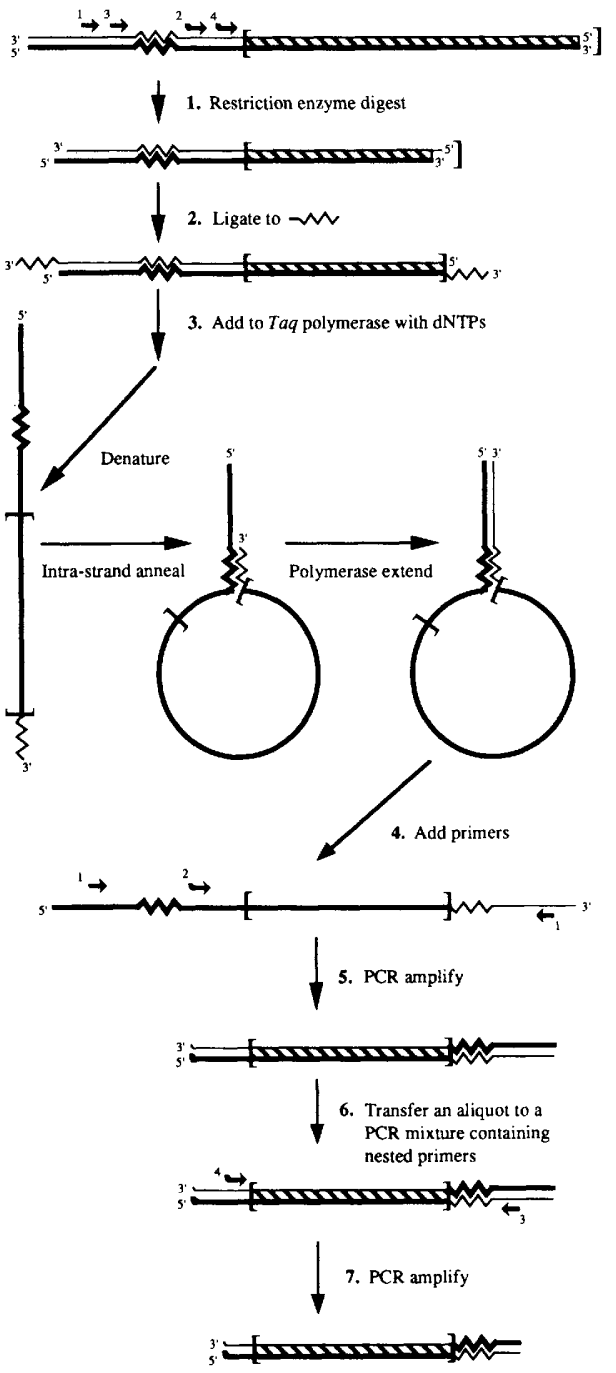

FIGURE 1 Panhandle PCR. The numbered steps correspond to the numbered steps in Materials and Methods. The two complementary strands of genomic DNA are thin and thick lines. DNA that flanks the known region of genomic DNA is enclosed by brackets and is striped when double-stranded. The jagged portion of the thick line represents the annealing region for the ligated oligonucleotide. The PCR primers are numbered arrows. The locations of the primers in relation to the relevant strands of genomic DNA are shown at top for step 1, and the primers are not used until step 4. One or two nucleotides are added to the $5^{\prime}$ ends of primers 2 and 4 that are not complementary to their template, and are represented by upended 5 ' ends.

tion: one that is homologous to the region upstream to the annealing site for the ligated oligonucleotide (Fig. 1, primer 1 and 3 ) and one that is homologous to a region located between the ligated oligonucleotide annealing site and the unknown flanking DNA (Fig. 1, primer 2 and 4). Use of one primer in each amplification (primer 1 alone in the first PCR amplification and primer 3 in the second primer amplification) amplified poorly (not shown), presumably due to large inverted repeats in the ends of each PCR product, which may compete with primer annealing. Primers 2 and 4 have 1 or 2 nucleotides added to the $5^{\prime}$ end that are not homologous to the original template. This is done as a precaution, to prevent short-circuiting of the amplification reaction. Such short-circuiting could occur by annealing of the 3' end of a strand of a short, nonspecific PCR product (into which primer 2 or 4 was incorporated) to the targeted sequence, resulting in a short, nonspecific product. Because this precaution is simple and inexpensive, its necessity has not been tested. This paper illustrates that this method can amplify longer products, with higher specificity, than previously reported methods.

\section{MATERIALS AND METHODS}

\section{Oligonucleotide Synthesis}

Oligonucleotides were synthesized by Midland Certified Reagent Company (Midland, TX). Oligonucleotides with a phosphorylated 5 ' end were generated during oligonucleotide synthesis by addition of a phosphorylated phosphoramidite. The sequences of the oligonucleotides and $T_{\mathrm{m}}$ values are given in Tables 1 and $2 . T_{\mathrm{m}}$ values were obtained using the computer program OLIGO 3,4 (National BioSciences, Hamel, NM).

\section{Restriction Enzyme Digestion Followed by Calf Intestinal Alkaline Phosphatase Treatment}

\section{(Step 1)}

Five micrograms of human genomic DNA (Clontech, Palo Alto, CA) was digested with $20-40$ units of a restriction enzyme that yields a $5^{\prime}$ overhang (XbaI, AvrII, BamHI, BclI, BglII, BspDI, BstBI, or MluI; New England BioLabs, Beverly, $\mathrm{MA}$ ) in $100 \mu \mathrm{l}$ for $2 \mathrm{hr}$. The digested genomic DNA was dephosphorylated by the addition of 0.05 units of calf intestinal alkaline phosphatase in $5 \mu$ l (Boehringer Mannheim Biochemicals, Indianapolis, IN) with incubation at $37^{\circ} \mathrm{C}$ for $30 \mathrm{~min}$. The DNA underwent glass bead extraction using Geneclean (BIO 101, La Jolla, CA), and was suspended in $50 \mu \mathrm{l}$ of TE buffer (10 mM Tris- $\mathrm{HCl}, \mathrm{pH} .8,1 \mathrm{~mm}$ EDTA). Five 5- $\mu$ l aliquots were frozen for later use as nonoligonucleotide-ligated template controls.

\section{Ligation of Phosphorylated Oligonucleotide}

\section{(Step 2)}

The remaining $25 \mu \mathrm{l}$ of genomic DNA was ligated to a 50-fold molar excess of a $5^{\prime}$ phosphorylated oligonucleotide (whose $5^{\prime}$ end is complementary to the single-stranded ends of restriction enzyme-digested genomic DNA) in $\mathrm{T}_{4}$ DNA ligase buffer (50 mM Tris- $\mathrm{HCl}, \mathrm{pH} 7.6,10$ $\mathrm{mM} \mathrm{MgCl}_{2}, 0.5 \mathrm{~mm}$ ATP, $10 \mathrm{~mm}$ dithio-

TABLE 1 Sequence of Oligonucleotides Used in Retrieval of Human Genomic $\beta$-globin DNA

Oligonucleotide phosphorylated at the 5 ' end, ligated to $X b a$ I-digested genomic DNA

5'p-CTAGAGTCTTCTCTGTCTCCACATGCCCAGTTTCTATTGGTC. $T_{\mathrm{m}}$ of the 40-nucleotidelong $3^{\prime}$ region of this oligonucleotide that is complementary to the known region of genomic DNA is $71.5^{\circ} \mathrm{C}$.

PCR amplification oligonucleotides Primer 1:

Primer 2:

Primer 3 (nested primer):

Primer 4 (nested primer):
GATGAAGTTGGTGGTGAGGCCCTG. $T_{\mathrm{m}} 62.5^{\circ} \mathrm{C}$ GACTTGGGTTTCTGATAGGCACTGACTCTC. $5^{\prime}$ nucleotides that are not complementary to $\beta$-globin are underlined; $T_{\mathrm{m}} 62.6^{\circ} \mathrm{C} ; T_{\mathrm{m}}$ minus $5^{\prime} \mathrm{GA}, 60.7^{\circ} \mathrm{C}$ GTTGGTATCAAGGTTACAAGACAGGTTTAAGGAG. $T_{\mathrm{m}}$, $62.4^{\circ} \mathrm{C}$.

GACTGCCTATTGGTCTATTTTCCCACCCTTAG. 5' nucleotides not complementary to $\beta$-globin are underlined; $T_{\mathrm{m}}, 64.5^{\circ} \mathrm{C} ; T_{\mathrm{m}}$ minus $5^{\prime} \mathrm{GA}, 62.9^{\circ} \mathrm{C}$. 
TABLE 2 Oligonucleotides Used to Retrieve Human Genomic DNA Flanking 5' End of the CFTR CDNA

\begin{tabular}{|c|c|}
\hline \multirow{2}{*}{\multicolumn{2}{|c|}{$X b a$ I or Avr II digeste }} \\
\hline & \\
\hline \multicolumn{2}{|c|}{$\begin{array}{l}\text { 5'p-CTAGCTTGAGCCCAGACGGCCCTAGCAGGGAC. } T_{\mathrm{m}} \text { of the } 30 \text {-nucleotide-long } 3 \text { region } \\
\text { of this oligonucleotide that is complementary to the known region of genomic DNA is } \\
74.0^{\circ} \mathrm{C}\end{array}$} \\
\hline \multicolumn{2}{|c|}{ Phosphorylated oligonucleotide ligated to BamHI-, Bcll-, or BglII-digested genomic DNA } \\
\hline \multicolumn{2}{|c|}{$\begin{array}{l}5^{\prime} \text { 'p-GATCGCTTGAGCCCAGACGGCCCTAGCAGGGAC. } T_{\mathrm{m}} \text { of the 29-nucleotide-long } 3^{\prime} \\
\text { region of this oligonucleotide that is complementary to the known region of genomic } \\
\text { DNA is } 73.8^{\circ} \mathrm{C}\end{array}$} \\
\hline \multicolumn{2}{|c|}{ Phosphorylated oligonucleotide ligated to BspDI-, BstBI-, or MluI-digested genomic DNA } \\
\hline \multicolumn{2}{|c|}{$\begin{array}{l}5^{\prime} \text { - } \text {-CGCGCTTGAGCCCAGACGGCCCTAGCAGGGAC. } T_{\mathrm{m}} \text { of the } 29 \text {-nucleotide-long } 3^{\prime} \text { region } \\
\text { of this oligonucleotide that is complementary to the known region of genomic DNA is } \\
73.8^{\circ} \mathrm{C}\end{array}$} \\
\hline \multicolumn{2}{|l|}{ CR amplification oligonucle } \\
\hline Primer 1: & TTTGGAGACAACC \\
\hline Prim & $\begin{array}{l}\text { GTAATGCCAAAGACCTACTACTCTGGGTGC. } 5^{\prime} \\
\text { nucleotide not complementary to CFTR underlined; } \\
T_{\mathrm{m} \prime} 62.3^{\circ} \mathrm{C} ; T_{\mathrm{m}} \text { minus } 5^{\prime} \mathrm{G}, 61.8^{\circ} \mathrm{C}\end{array}$ \\
\hline Prime & AGGCGACCTCTGCATGGTCTCTC. $T_{\mathrm{m}}, 60.6^{\circ} \mathrm{C}$ \\
\hline & $\begin{array}{l}\text { GCTGCCGCTCAACCCTTTTTCTCTG. } 5^{\prime} \text { nucleotide } \\
\text { not complementary to CFTR underlined; } T_{\mathrm{m}} 64.8^{\circ} \mathrm{C} ; \\
T_{\mathrm{m}} \text { minus } 5^{\prime} \mathrm{G}, 62.0^{\circ} \mathrm{C}\end{array}$ \\
\hline
\end{tabular}

threitol) using one Weiss unit of $\mathrm{T}_{4}$ DNA ligase (Boehringer Mannheim Biochemicals) at $23^{\circ} \mathrm{C}$ for $4 \mathrm{hr}$. The ligation mixture underwent GeneClean purification and was suspended in $25 \mu \mathrm{l}$ of TE buffer.

\section{Panhandle Formation}

\section{(Step 3)}

A $25-\mu l$ aliquot of $2 \times$ PCR mix [1.25 units of Taq (DNA) polymerase (AmpliTaq, Perkin-Elmer Cetus, Norwalk, CT), $100 \mathrm{~mm} \mathrm{KCl}, 20 \mathrm{~mm}$ Tris- $\mathrm{HCl}, \mathrm{pH} \mathrm{8.3,} 3$ $\mathrm{mM} \mathrm{MgCl}_{2} 0.02$ (wt/vol), gelatin and 400 $\mu \mathrm{M}$ each dNTP], prealiquoted and stored at $-20^{\circ} \mathrm{C}$, was thawed, $18 \mu \mathrm{l}$ of $\mathrm{H}_{2} \mathrm{O}$ was added, and $50 \mu$ l of mineral oil was layered on top. The tube was preheated to $80^{\circ} \mathrm{C}$ prior to addition of $2 \mu$ l of template, to prevent nonspecific annealing and polymerization. ${ }^{(28)}$ The mixture underwent the following temperature transitions on a thermal cycler (Perkin-Elmer Cetus original model): $95^{\circ} \mathrm{C}$ for $1 \mathrm{~min}$, a 2-min transition to $72^{\circ} \mathrm{C}$ for $30 \mathrm{sec}$ for the amplification of CFTR $\left(70^{\circ} \mathrm{C}\right.$ for the amplification of $\beta$-globin), then a rapid transition to an $80^{\circ} \mathrm{C}$-soak. Because the genomic DNA concentration was $<4 \mathrm{ng} /$ $\mu \mathrm{l}$, the denaturation and reannealing steps resulted in intrastrand annealing of the ligated synthetic oligonucleotide to its complementary sequence in the genomic DNA. ${ }^{(5)}$ This is followed by poly- merase extension of the recessed 3 ' end. Two additional tubes, one containing the control template (genomic DNA that had been digested, but not ligated to the phosphorylated oligonucleotide), and the other containing a reagent control (no DNA), were processed concurrently in all experiments.

\section{Set Up of Initial PCR Amplification}

\section{(Step 4)}

To each of the three tubes, 12.5 pmoles of each primer, in a total volume of $5 \mu 1$ of $\mathrm{H}_{2} \mathrm{O}$ was added under mineral oil while the tubes remained in the heat block at $80^{\circ} \mathrm{C}$, resulting in a final concentration of $0.25 \mu \mathrm{M}$ of each primer with $200 \mu \mathrm{M}$ of each dNTP.

\section{Initial PCR Amplification}

\section{(Step 5)}

All three tubes underwent thirty PCR amplification cycles. Parameters of amplification of $\beta$-globin and $<4 \mathrm{~kb}$ of CFTR were as follows: $95^{\circ} \mathrm{C}$ for $30 \mathrm{sec}$, $60^{\circ} \mathrm{C}$ for $30 \mathrm{sec}, 72^{\circ} \mathrm{C}$ for $3 \mathrm{~min}$, followed by a final extension at $72^{\circ} \mathrm{C}$ for $7 \mathrm{~min}$. Then, the reactants came to an $80^{\circ} \mathrm{C}$ soak. Amplification of $>4 \mathrm{~kb}$ of CFTR were identical, except the $72^{\circ} \mathrm{C}$ extension step was $4 \mathrm{~min}$ long.

\section{Set Up of Nested PCR Amplification}

(Step 6)

One microliter of the unpurified initial PCR amplification product was removed from each tube by inserting a long, thin pipette tip through the mineral oil layer, and then was placed in a corresponding second set of PCR tubes containing nested primers preheated to $80^{\circ} \mathrm{C}$ with the same enzyme, reagents, and primer concentrations as in the first PCR amplification.

\section{Nested PCR Amplification}

(Step 7)

All three tubes with the nested primers underwent thirty-five PCR amplification cycles with thermal cycling parameters identical to those used in the initial PCR amplification, except that the annealing temperature for the amplification of $\beta$-globin DNA was $62^{\circ} \mathrm{C}$.

\section{Detection of PCR Products}

Nine microliters of each PCR product was analyzed by agarose gel electrophoresis followed by ethidium bromide staining.

\section{Cloning of Individual PCR Products}

PCR products were cloned into pUC19 using recombination PCR. ${ }^{(29)}$ pUC19 was digested with HindIII. Then, $2 \mathrm{ng}$ of the linearized pUC19 underwent twenty cycles of PCR amplification using primers whose $5^{\prime}$ ends have 24 nucleotides that are complementary to the $5^{\prime}$ ends of the primers used in the nested primer PCR amplification of step 7. This resulted in a vector with ends that are homologous to the panhandle PCR product. A 2.5- $\mu$ l amount of each of two crude PCR products - the PCR-amplified and modified linear plasmid and the PCR product derived from the nested primers of step 7 of the panhandle PCR - was cotransfected into $10^{9}$ transformants/ $\mu \mathrm{g}$ of monomer pUC19 (MAX) efficiency DH5 $\alpha$-competent Escherichia coli (GIBCO BRL/Life Technologies, Gaithersburg, MD). Transformed clones were grown overnight in Luria-Bertani Medium (LB Medium) at $37^{\circ} \mathrm{C}$, and $2 \mu \mathrm{l}$ 
of the growth, without boiling or other extraction of plasmids, was screened for the recombinant by PCR amplification with M13 and RM13 primers, followed by minigel analysis.

\section{Identification of PCR Products}

Plasmids were purified by Qiagen-tip 100 columns (Qiagen Inc., Studio City, CA). The ends of the plasmid inserts were sequenced by the dideoxy $\operatorname{method}^{(30)}$ using Sequenase version 2.0 (U.S. Biochemical, Cleveland, $\mathrm{OH}$ ) following the manufacturer's protocol and using standard M13 and RM13 primers (Pharmacia, Pleasant Hill, CA) to identify the inserts.

\section{RESULTS}

In an attempt to amplify $>3 \mathrm{~kb}$ of human genomic DNA that flanks the primer annealing sites, 3120 bp of $\beta$-globin DNA, containing 3017 bp of flanking DNA, was amplified using four amplification primers with annealing sites that flank one side of this sequence. This 3017 bp of flanking DNA consists of the last base pair of the first intron, the remaining 1333 bp of the $\beta$-globin gene, and $1683 \mathrm{bp}$ flanking the $3^{\prime}$ end of the $\beta$-globin gene. ${ }^{(24)}$ The PCR amplifications were carried out on bulk genomic DNA. A control template and reagent control were also amplified (see Materials and Methods). Nine microliters of each of the three final PCR products were run on a $1 \%$ agarose gel. Samples with genomic DNA generated a background smear of DNA, but only the tube that initially contained the genomic DNA following $X b a$ I digestion, calf intestinal alkaline phosphatase treatment, and ligation to the phosphorylated oligonucleotide yielded a distinct DNA band (see Fig. 2, lane 2 ) This product migrated at the predicted size and was subcloned using the recombination PCR method and the crude PCR mix without prior isolation of the band. Sequencing of the insert ends of four clones confirmed that the product of interest was obtained.

Using a separate set of primers that anneal to the CFTR CDNA sequence, the panhandle PCR method was used to amplify the G/C-rich DNA sequence immediately upstream to the CFTR cDNA using four amplification primers. A 2303bp DNA fragment, containing 2216 bp of DNA flanking the primer annealing sites,

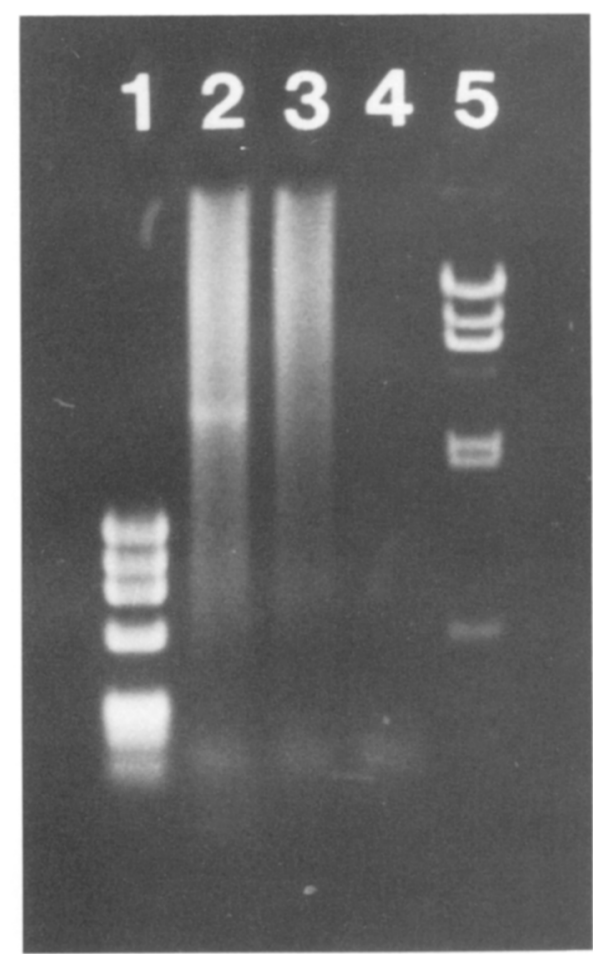

FIGURE 2 PCR amplification of a portion of the human $\beta$-globin gene directly from human genomic DNA using four primers that initially flank only one side of the amplified region, run on an agarose gel. (Lane 1) $\phi X 174$ Haelll molecular weight markers; (lane 2) human genomic DNA after $X b a l$ digestion, calf intestinal alkaline phosphatase treatment, and ligation to phosphorylated oligonucleotide; (lane 3) human genomic DNA after $X b a I$ digestion and calf intestinal alkaline phosphatase treatment without ligation to phosphorylated oligonucleotide; (lane 4) no template control; (lane 5) $\lambda$ HindIII molecular weight markers.

was amplified (see Fig. 3A) and, in a separate experiment, a 3644-bp DNA fragment containing 3557 bp of DNA flanking the primer annealing sites was amplified (see Fig. 3B). The PCR amplifications were carried out on bulk genomic DNA and rendered the fragment of interest with high specificity. A control template and reagent control were also amplified (see Materials and Methods). In each experiment, $9 \mu$ l of each of the three final PCR products were run on a $1 \%$ agarose gel, and only the tube that initially contained the genomic DNA following restriction enzyme digestion (XbaI in Fig. 3A; AvrII in Fig. 3B), calf intestinal alkaline phosphatase treatment, and ligation to the phosphorylated oligonucleotide, yielded a detect- able product following ethidium bromide staining (Fig. 3, A and B, lane $2)$. The two products were subcloned using the recombination PCR method. Sequencing of the insert ends of four clones from each experiment revealed the product of interest.

In an attempt to amplify $>4 \mathrm{~kb}$ of genomic DNA that flanked the PCR primer annealing sites and obtain new sequence information, human genomic DNA was digested with several restriction enzymes that were known not to cut within the previously sequenced 3764 bp of human genomic DNA that lies upstream to the CFTR CDNA sequence originally described..$^{(25,26)}$ The $5^{\prime}$ end of the ligated oligonucleotide was modified to permit ligation to the restriction enzyme-digested genomic DNA ends (see Table 2). The remainder of the oligonucleotides were identical to those used to amplify $<4 \mathrm{~kb}$ of CFTR. The enzymes tested were $B a m \mathrm{HI}, B c l \mathrm{I}, B g l \mathrm{II}, B s p \mathrm{DI}, B s t \mathrm{BI}$, and $M l u \mathrm{I}$. One of the enzymes, $B c l$, yielded a product of $>4 \mathrm{~kb}$ (see Fig. 4A). This product was subcloned using recombination PCR. Sequence analysis of the ends of each insert in four separate clones revealed that each gave a predicted 4510bp product, with 4423 bp flanking the primer annealing sites, including $630 \mathrm{bp}$ of new sequence information located upstream to the previously sequenced CFTR promoter and regulatory sequence. ${ }^{(26)}$ The new sequence information was located from $-4394 \mathrm{bp}$ to $-3765 \mathrm{bp}$ from the first nucleotide of the originally described CFTR cDNA. ${ }^{(25)}$ This segment was sequenced in each of the four clones and is shown in Figure 4B. The first 226 nucleotides (bases -4394 to -4169 ) are part of an Alu sequence. $^{(31)}$ PCR was applied to unmodified genomic DNA to confirm the sequence located from -4375 bp to -3765 bp relative to the DNA sequence and also to confirm the presence of two alleles, one with an $\mathrm{A}$ at position -4332 and the other allele with a $\mathrm{T}$ at that position (data not shown). The locations of the PCR primers and annealing site for the ligated oligonucleotide, relative to the cDNA CFTR sequence, are shown in Figure $4 \mathrm{C}$.

\section{DISCUSSION}

These results illustrate the power of the panhandle PCR method. Previously published methods have not been successful 

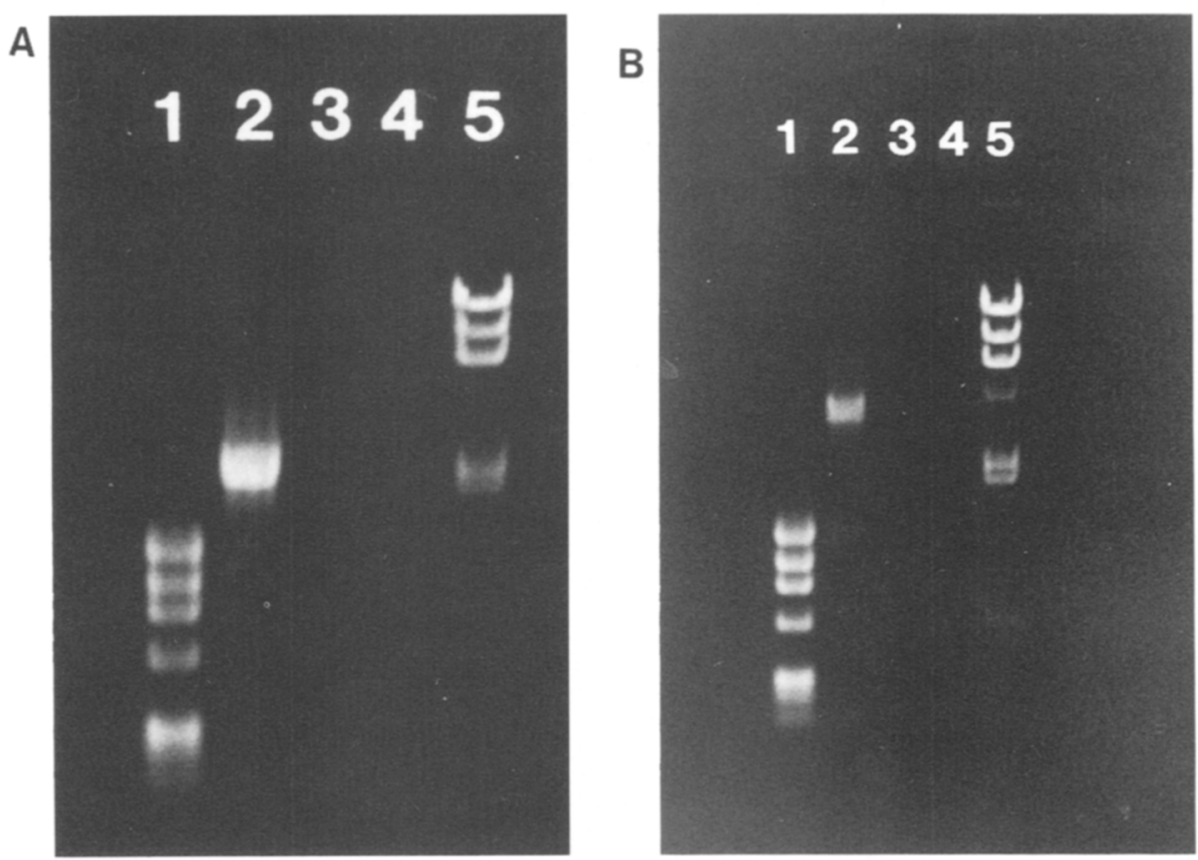

FIGURE $3(A)$ PCR amplification of the sequence 5 to the CFTR gene directly from human genomic DNA using four primers derived from cDNA data, run on an agarose gel. (Lane 1) $\phi X 174$ HaelII molecular weight markers; (lane 2) human genomic DNA after XbaI digestion and calf intestinal alkaline phosphatase treatment, and ligation to phosphorylated oligonucleotide; (lane 3) human genomic DNA following XbaI digestion and calf intestinal alkaline phosphatase treatment without ligation to phosphorylated oligonucleotide; (lane 4) no template control; (lane 5) $\lambda$ HindIII molecular weight markers. (B) PCR amplification of 5'-flanking region of the CFTR gene directly from human genomic DNA using four primers derived from cDNA data, run on an agarose gel. (Lane 1) \$X174 HaelII molecular weight markers; (lane 2) human genomic DNA after AvrII digestion, calf intestinal alkaline phosphatase treatment, and ligation to phosphorylated oligonucleotide; (lane 3 ) human genomic DNA after AvrII digestion and calf intestinal alkaline phosphatase treatment without ligation to phosphorylated oligonucleotide; (lane 4 ) no template control; (lane 5 ) $\lambda$ HindIII molecular weight markers.

in the highly specific PCR amplification of large fragments $(>2 \mathrm{~kb}$ ) flanking the primer annealing sites from bulk genomic DNA. The method detailed in this paper differs from the initial description of this method in the following aspects: (1) A partial fill-in of the genomic DNA was not used, thereby avoiding sequence artifacts that have been encountered previously, ${ }^{(23)}$ and (2) longer primers were used to amplify $>2 \mathrm{~kb}$ of DNA, permitting higher annealing temperatures during the PCR amplifications. This has resulted in very high specificity and allows the retrieval of large segments of DNA. Applications of a method that permits the PCR amplification of large segments of DNA flanking a known region include the following: chromosome walking, retrieval and sequencing of unclonable DNA, amplification of fragments adjacent to CDNA, such as regulatory regions and intron-exon junctions, determination of the insertion sites of viruses, tranposons, or other DNA fragments, generation of yeast artificial chromosome (YAC) endpoints, ${ }^{(13)}$ generation of chro- mosome linking fragments, and chromosome jumping. ${ }^{(7)}$

The original method developed for the amplification of unknown flanking DNA is inverse PCR. ${ }^{(4-6)}$ Inverse PCR permits amplification of DNA flanking a known sequence by circularization of restriction enzyme-digested DNA. This permits amplification of the flanking sequence by positioning two primers, each of which binds to the known sequence inside-out, on the circle. Therefore, this strategy maintains specificity at each primer binding site. Difficulties with inverse PCR include the requirement for two restriction sites that flank the priming region and inefficient PCR amplification of closed circular DNA, if a convenient restriction enzyme is not present between the two $5^{\prime}$ ends of the amplifying primers. ${ }^{(6)}$ Nicking the circles by heating is reported to ameliorate the difficulty in amplifying closed circular double-stranded $\mathrm{DNA}^{(5,6)}$; however, only a small percentage of the circles would be expected to be nicked between the two 5 ' ends of the amplifying primers, and thus, any increase in the initial amplification efficiency would suboptimal. Inverse PCR is also characterized by the generation of concatemers. ${ }^{(32)}$ This may result from the polymerase-dependent $5^{\prime}$ exonuclease activity of Taq polymerase, resulting in nick translation following polymerase extension from a single primer along a circular template. This nick translation would result in a product that can splice into the intended PCR product by polymerization during a thermal cycle, generating a concatemer.

There are three other methods for the PCR amplification of unknown flanking DNA that have recently generated widespread interest: ligation $\mathrm{PCR}^{(15-17,22)}$ vectorette $P C R,{ }^{(13,18)}$ and capture PCR. ${ }^{(14,19)}$ In each of these methods, there is an initial PCR amplification step in which one primer anneals to a site that is specific for the product of interest and the other primer anneals to a universal site, appended by ligation. Each of the three methods has a distinct strategy that selects for products from the specific primer, before PCR amplification, 
A

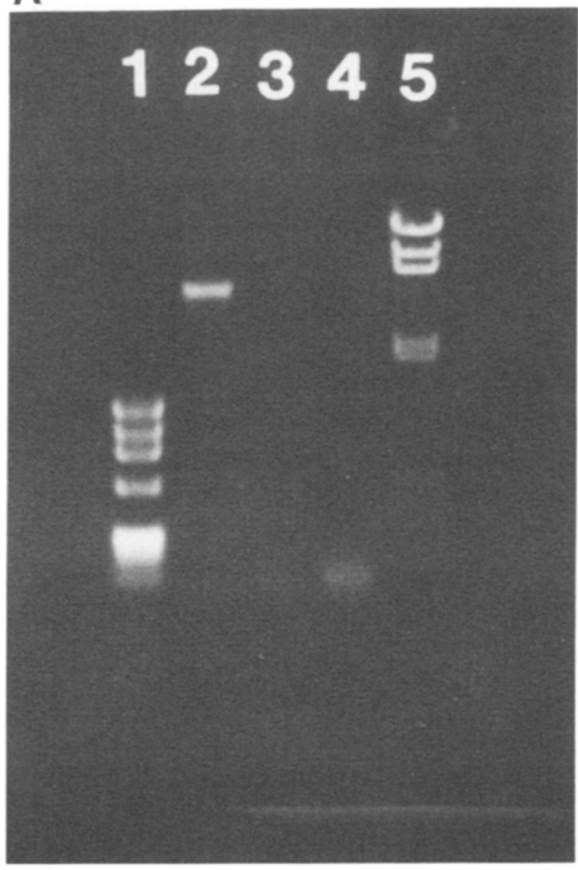

B

TGATCACAGCTCACTGCAGCCTCGATCTCCCAGGCTCAAGCCATCCACCTGCCTC

-4340 AGCCTCCC(A/T)AGTAGCTGAGATCAGAAGCATGCACCACCACACCTGGCTAT

-4290 TTTTTTTATTTTTTTGTAGAGACAAGGTCTTACTGTGTTGCCCAGGCTGA

-4240 TCTCAAACTCCTGAGCTCAAGCAATCCTCCTGCCTCAGCTTCTCAAAGTT

-4190 CTGGGATTACAGGCATGAGCCATGGCACCTGACCAAGGTGAGTGTATTTA

-4140 ACCTCATTTTCAGGCAAGGAAACAAAAGACAGAAAAGTTAAGTAGCTTAC

-4090 TTAAGGTCACAGAGCTAAGTGTGGTGCCAGGATTGAAAACCTAGTTCTTT

-4040 ATTGCTTTAGCACAAGCTATTTCCACTATACTCTGTCATGTTCAGAGAAT

-3990 GTTGATGTCCATCAGTGGATTCTAAATTTTGAAGGATGGAGATACTGCCT

-3940 TATTCTGTACATCTGCTTTAGCACCCAAGCTCTTGCTTGGTGAAAAATTA

-3890 ATAGTAAACATTCATCTTTTGAGCATCTTCAAATATCCCCTTTAGAATGA

-3840 CATTCAACTATTAGGTCAGTAACCCCAAGAGAAAACGGTTGTTTGAGTGT

-3790 ATATACTGTATTACAAAATAAGGGGT

C

primer \#1 primer \#3

5' TITGGaGaCAaCGCTGGCCTHTCC 5' AGGCGaCCTCTGCATGGTCTCTC

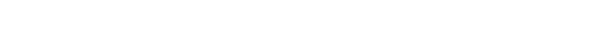

5. AGTTH

$+185$

FIGURE 4 ( $A$ ) PCR amplification of 5 '-flanking region of CFTR gene directly from human genomic DNA using four primers derived from cDNA data, run on an agarose gel. (Lane 1) $\phi X 174$ HaeIII molecular weight markers; (lane 2) human genomic DNA after BclI digestion, calf intestinal alkaline phosphatase treatment, and ligation to phosphorylated oligonucleotide; (lane 3) human genomic DNA following Bcll digestion, and calf intestinal alkaline phosphatase treatment without ligation to phosphorylated oligonucleotide; (lane 4) no template control; (lane 5) $\lambda$ HindIII molecular weight markers. $(B)$ DNA sequence -4394 bp to -3765 bp upstream to the CFTR cDNA sequence. The first nucleotide of the published CFTR cDNA sequence is numbered at the +1 position. The $B c l$ recognition site is boxed. The sequence from -4375 to -3765 has been confirmed by conventional PCR and is entered in GenBank under accession numbers (L06116 and L06117). (C) Positions of the PCR primer sequences and of the ligated oligonucleotide annealing site used to amplify DNA upstream to CFTR using panhandle PCR. The template is numbered according to the cDNA sequence, with the first nucleotide of the published cDNA sequence in the +1 position. ${ }^{(25)}$ The PCR primers are underlined and the ligated oligonucleotide is boxed. The single $5^{\prime}$ nucleotides of primers 2 and 4 that are not homologous to the template are in bold type. The sequence of the ligated oligonucleotide in this figure was used to amplify the $4.5 \mathrm{~kb}$ of DNA shown in $A$, and the product included the new sequence shown in $B$. The sequence of this template strand is from the strand antisense to that in $B$, because the panhandle template depicted here, and corresponding to the schematic template in step 3 of Fig. 1, is the antisense strand relative to CFTR cDNA.

using the specific and nonspecific primer. Nevertheless, some nonspecific products generated from the specific primer are not discriminated against, because the generation of the initial template does not depend upon priming from a unique sequence from the unknown end. Specificity is increased by a heminested PCR amplification step, in which the universal primer annealing site is used in conjunction with a down- stream-specific site. In the panhandle PCR method described, the placement of known DNA on the opposite end of the strand of interest requires sequence-specific annealing at high stringency, and the primer annealing sites on the unknown end of the strand of interest are unique to that strand. Therefore, a fullnested PCR amplification can be carried out, as opposed to a heminested PCR amplification in other methods, resulting in very high specificity. Panhandle PCR, thus, extends the application of PCR to the retrieval of $>2 \mathrm{~kb}$ of DNA where the DNA sequence is known at only one end.

\section{ACKNOWLEDGMENTS}

This work was supported by National Institutes of Health grant 1RO1 HG0056901 and by the Roy J. Carver Charitable Trust. 


\section{REFERENCES}

1. Mullis, K., F. Faloona, S. Scharf, R. Saiki, G. Horn, and H. Erlich. 1986. Specific enzymatic amplification of DNA in vitro: The polymerase chain reaction. Cold Spring Harbor Symp. Quant. Biol. 51: 263-273.

2. Saiki, R.K., S. Scharf, F. Faloona, K.B. Mullis, G.T. Horn, H.A. Erlich, and N. Arnheim. 1985. Enzymatic amplification of $\beta$-globin genomic sequences and restriction site analysis for diagnosis of sickle cell anemia. Science 230: 1350-1354.

3. Saiki, R.K., D.H. Gelfand, S. Stoffel, S.J. Scharf, R. Higuchi, G.T. Horn, K.B. Mullis, and H.A. Erlich. 1988. Primer-directed enzymatic amplification of DNA with a thermostable DNA polymerase. Science 239: 487-491.

4. Ochman, H., A.S. Gerber, and D.L. Hartl. 1988. Genetic approaches of an inverse polymerase chain reaction. Genetics 120: $621-623$.

5. Triglia, T., M.G. Peterson, and D.J. Kemp. 1988. A procedure for in vitro amplification of DNA segments that lie outside the boundaries of known sequences. Nucleic Acids Res. 16: 8186.

6. Silver, J. and V. Keerikatte. 1989. Novel use of polymerase chain reaction to amplify cellular DNA adjacent to an integrated provirus. J. Virol. 63: 1924-1928.

7. Kandpal, R.P., H. Shukla, D.C. Ward, and S.M. Weissman. 1990. A polymerase chain reaction approach for constructing jumping and linking libraries. Nucleic ACids Res. 18: 3081.

8. Frohman, M.A., M.K. Dush, and G.R. Martin. 1988. Rapid production of full-length cDNAs from rare transcripts: Amplification using a single gene-specific oligonucleotide primer. Proc. Natl. Acad. Sci. 85: 8998-9002.

9. Loh, E.Y., J.F. Elliott, S. Cwirla, L.L. Lanier, and M.M. Davis. 1989. Polymerase chain reaction with single sided specificity: Analysis of T cell receptor $\delta$ chain. Science 243: $217-220$.

10. Ohara, O., R.L. Dorit, and W. Gilbert. 1989. One-sided polymerase chain reaction: The amplification of cDNA. Proc. Natl. Acad. Sci. 86: 5673-5677.

11. Shymala, V. and G.F.-L. Ames. 1990 . Genome walking by single-specific-primer polymerase chain reaction: SSP-PCR. Gene 84: 1-8.

12. Parker, J.D., P.S. Rabinovitch, and G.C. Burmer. 1991. Targeted gene walking polymerase chain reaction. Nucleic Acids Res. 19: 3055-3060.

13. Riley, J., R. Butler, D. Ogilvie, R. Finniear, D. Jenner, S. Powell, R. Anand, J.C. Smith, and A.F. Markham. 1990. A novel, rapid method for the isolation of terminal sequences from yeast artificial chromosome (YAC) clones. Nucleic Acids Res. 18: 28872890.
14. Rosenthal, A. and D.S.C. Jones. 1990 . Genomic walking and sequencing by oligocassette mediated polymerase chain reaction. Nucleic Acids Res. 18: 3095-3096.

15. Pfeifer, G.P., S.D. Steigerwald, P.R. Mueller, B. Wold, and A.D. Riggs. 1989. Genomic sequencing and methylation analysis by ligation mediated PCR. Science 246: 810-813.

16. Mueller, P.R. and B. Wold. 1989. In vivo footprinting of a muscle specific enhancer by ligation mediated PCR. Science 246: 780-786.

17. Fors, L., R.A. Saavedra, and L. Hood. 1990. Cloning of the shark Po promoter using a genomic walking technique based on the polymerase chain reaction. Nucleic Acids Res. 18: 2793-2799.

18. Arnold, C. and I.J. Hodgson. 1991. Vectorette PCR: A novel approach to genomic walking. PCR Methods Applic. 1: 39-42.

19. Lagerstrom, M., J. Parik, H. Malmgren, J. Stewart, U. Pettersson, and U. Landegren. 1991. Capture PCR: Efficient amplification of DNA fragments adjacent to a known sequence in human and YAC DNA. PCR Methods Applic. 1: 111-119.

20. Roux, K.H. and P. Dhanarajan. 1990. A strategy for single site PCR amplification of dsDNA: Priming digested cloned or genomic DNA from an anchor-modified restriction site and a short internal sequence. BioTechniques 8: 48-57.

21. MacGregor, G.R. and P.A. Overbeek. 1991. Use of a simplified single-site PCR to facilitate cloning of genomic DNA sequences flanking a transgene integration site. PCR Methods Applic. 1: 129-135.

22. Garrity, P.A. and B.J. Wold. 1992. Effects of different DNA polymerases in ligationmediated PCR: Enhanced genomic sequencing and in vivo footprinting. Proc. Natl. Acad. Sci. 89: 1021-1025.

23. Jones, D.H. and S.C. Winistorfer. 1992. Sequence specific of a DNA panhandle permits PCR amplification of unknown flanking DNA. Nucleic Acids Res. 20: 595600.

24. Lawn, R.M., A. Efstratiadis, C. O'Connell, and T. Maniatis. 1980. The nucleotide sequence of the human $\beta$-globin gene. Cell 21: $647-651$.

25. Riordan, J.R., J.M. Rommens, B.-S. Kerem, N. Alon, R. Rozmahel, Z. Grzelczak, J. Zielenski, S. Lok, N. Plavsic, J.-L. Chou, M.L. Drumm, M.C. Iannuzzi, R.S. Collins, and L.-C. Tsui. 1989. Identification of the cystic fibrosis gene: Cloning and characterization of complementary DNA. Science 245: 1066-1072.

26. Yoshimura, K., H.N. Nakamura, B.C. Trapnell, W. Dalemans, A. Pavirani, J.-P. Lecocq, and R.C. Crystal. 1991. The cystic fibrosis gene has a "housekeeping"-type promoter and is expressed at low levels in cells of epithelial origin. J. Biol. Chem. 266: 9140-9144.
27. Zielenski, J., R. Rozmahel, D. Bozon, B.-S. Kerem, Z. Grzelczak, J.R. Riordan, J. Rommens, and L.-C. Tsui. 1991. Genomic DNA sequence of the cystic fibrosis transmembrane conductase regulator (CFTR) gene. Genomics 10: 214-228.

28. Mullis, K.B. 1991. The polymerase chain reaction in an anemic mode: How to avoid cold oligodeoxyribonuclear fusion. PCR Methods and Applic. 1: 1-4.

29. Jones, D.H. and S.C. Winistorfer. 1991. Site-specific mutagenesis and DNA recombination by using PCR to generate recombinant circles in vitro or by recombination of linear PCR products in vivo. Methods: A Companion to Methods Enzymol. 2: 2-10.

30. Sanger, F., S. Nicklen, and A.R. Coulson. 1977. DNA sequencing with chain-terminating inhibitors. Proc. Natl. Acad. Sci. 74: 5463-5467.

31. Deininger, P.L., D.J. Jolly, C.M. Rubin, T. Friedmann, and C.W. Schmid. 1981. Base sequence studies of 300 nucleotide renatured repeated human DNA clones. J. Mol. Biol. 151: 17-33.

32. Green, I.R. and D.R. Sargan. 1991. Sequence of the cDNA encoding ovine tumor necrosis factor- $\alpha$ : Problems with cloning by inverse PCR. Gene 109: 203210.

Received September 11, 1992; accepted October 22, 1992. 


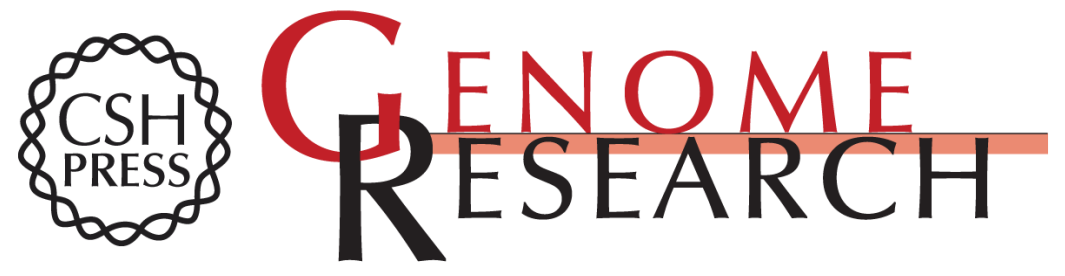

\section{Genome walking with 2- to 4-kb steps using panhandle PCR.}

D H Jones and S C Winistorfer

Genome Res. 1993 2: 197-203

Access the most recent version at doi:10.1101/gr.2.3.197

References This article cites 32 articles, 14 of which can be accessed free at:

http://genome.cshlp.org/content/2/3/197.full.html\#ref-list-1

\section{License}

Email Alerting Receive free email alerts when new articles cite this article - sign up in the box at the Service top right corner of the article or click here.

\section{Affordable, Accurate Sequencing.}

To subscribe to Genome Research go to: https://genome.cshlp.org/subscriptions 